Boston University School of Law

Scholarly Commons at Boston University School of Law

Faculty Scholarship

Spring 2021

\title{
Secular Invocations and the Promise of Religious Pluralism
}

Jay D. Wexler

Boston University School of Law

Follow this and additional works at: https://scholarship.law.bu.edu/faculty_scholarship

Part of the Religion Law Commons

\section{Recommended Citation}

Jay D. Wexler, Secular Invocations and the Promise of Religious Pluralism, in 26 Roger Williams University Law Review 620 (2021).

Available at: https://scholarship.law.bu.edu/faculty_scholarship/981

This Article is brought to you for free and open access by Scholarly Commons at Boston University School of Law. It has been accepted for inclusion in Faculty Scholarship by an authorized administrator of Scholarly Commons at Boston University School of Law. For more information, please contact lawlessa@bu.edu.

BOSTON

UNIVERSITY 


\section{Roger Williams University Law Review}

Volume 26

Issue 2 Vol. 26: No. 2 (Spring 2021)

Article 9

Symposium: Is This a Christian Nation?

Spring 2021

\section{Secular Invocations, the First Amendment, and the Promise of Religious Pluralism}

Jay Wexler

Boston University School of Law

Follow this and additional works at: https://docs.rwu.edu/rwu_LR

Part of the First Amendment Commons, and the Religion Law Commons

\section{Recommended Citation}

Wexler, Jay (2021) "Secular Invocations, the First Amendment, and the Promise of Religious Pluralism," Roger Williams University Law Review. Vol. 26 : Iss. 2 , Article 9.

Available at: https://docs.rwu.edu/rwu_LR/vol26/iss2/9

This Article is brought to you for free and open access by the School of Law at DOCS@RWU. It has been accepted for inclusion in Roger Williams University Law Review by an authorized editor of DOCS@RWU. For more information, please contact mwu@rwu.edu. 


\title{
Secular Invocations, the First Amendment, and the Promise of Religious Pluralism
}

\author{
Jay Wexler*
}

\section{INTRODUCTION}

The question posed by the Symposium is: "Is This a Christian Nation?" As someone who has recently published a book called "Our Non-Christian Nation,"1 it was probably clear to the organizers what my view would be on the matter. In that book, I described how, in a series of decisions over the course of the past two decades, the Supreme Court has opened up public lifegovernment property, institutions, and money-to religion and how, even though those decisions all of course benefitted the nation's Christian majority, recently, non-Christians, including Atheists and other secularists, have rightly begun taking advantage of those decisions to participate in public life alongside the majority. ${ }^{2}$

Thus, when the Court held in Zelman v. Simmons-Harris and Mitchell v. Helms that the government has wide discretion to funnel public money to Christian schools, ${ }^{3}$ Muslim schools and

* Professor of Law, Boston University School of Law. Many thanks to Conner Kingsley for terrific research assistance and to the organizers of the "Is This a Christian Nation?" conference for inviting me to participate.

1. Jay WeXler, Our Non-Christian Nation: How Atheists, Satanists, Pagans, and Others Are Demanding Their Rightful Place in Public Life (2019).

2. Id. at $6-8$.

3. Zelman v. Simmons-Harris, 536 U.S. 639, 662-63 (2002); Mitchell v. Helms, 530 U.S. 793, 801 (2000). 
organizations representing all types of religious beliefs, from Scientology to the Hare Krishnas, started asking for (and receiving) public money as well. 4 When the Court in Good News Club v. Milford Central School held that public schools must allow proselytizing Christian groups to use their classrooms after the end of the school day, 5 secularists and Satanists started running their own clubs in those same classrooms. 6 When the Court held in Capitol Square Review and Advisory Board $v$. Pinette that the government can let private Christian groups put up their displays and monuments on government property opened up as a public forum, 7 Wiccans and Atheists started putting up their own monuments in those forums. 8 And when the Court said in Town of Greece v. Galloway that town boards can start their meetings off with sectarian prayers, so long as they do not discriminate on the basis of religion, 9 individuals with all sorts of religious and nonreligious beliefs, from Hindus to Pagans to Satanists to secularists, started asking to give their own invocations, and many have in fact done so. 10

This phenomenon represents the fact that religious minorities (and nonbelievers, though from here on in I will simply include nonbelievers as a type of religious minority) have largely recognized that the Supreme Court is no longer particularly interested in keeping religion and the government separate. Prior to the Court's recent rightwing turn, exemplified by the appointment of separation skeptics such as Samuel Alito and Neil Gorsuch, the typical approach taken by minorities to church-state relations was to stay out of public life and fight in the courts for a jurisprudence more amenable to separationism. 11 After all, one of the great promises of the Establishment Clause has always been to protect minorities from both the symbolic and substantive dominance of the

4. See WeXLER, supra note 1 , at $113,115,117,120-21,123$.

5. Good News Club v. Milford Cent. Sch., 533 U.S. 98, 112 (2001).

6. See WEXLER, supra note 1, at 149-51.

7. Capitol Square Review \& Advisory Bd. v. Pinette, 515 U.S. 753, 76970 (1995).

8. See WEXLER, supra note 1 , at 44-49.

9. Town of Greece v. Galloway, 572 U.S. 565, 591-92 (2014).

10. See WEXLER, supra note 1 , at 63.

11. See, e.g., Van Orden v. Perry, 545 U.S. 677, 681 (2005); Zelman v. Simmons-Harris, 536 U.S. 639, 643-44 (2002). 
Christian majority by creating a largely religion-free zone of public life where everyone, regardless of their religious views, feels equally valued and respected. But as the Court's approach to the Establishment Clause has changed over time (it is notable that the Court has not invalidated a single government practice under the clause in over fifteen years12) and with the recent personnel changes practically guaranteeing that this trend will continue for at least another generation, religious minorities have realized that we (as an Atheist I include myself here) need a new strategy to at least try to counter the dominance of the Christian majority in what might accurately now be described as a "post-separationist" America.

In Our Non-Christian Nation, I argued that while a secular public square might be the ideal from the perspective of religious minorities, the religiously cacophonous public square created by this new movement is both the best option for minorities given the circumstances at the Supreme Court and, in fact, presents at least some unique possibilities to promote the interests of minorities even compared to the hypothetical secular public square. 13 For instance, participating in public life can be experienced as empowering for religious minorities in a way that staying away from it cannot be, and a public square filled with religious and nonreligious voices of all kinds might result in a citizenry better educated with respect to religion and religious diversity than an entirely secular public square. 14 Moreover, although the question is an empirical one with no clear answer yet, it is at least possible that a religiously diverse public square might result in more toleration and mutual respect among those who hold different beliefs and create the conditions for a more stable social peace than pure separationism. 15 In any event, insisting on participating alongside Christians in public life has got to be a better option from the perspective of religious minorities than ceding the public square entirely to the majority. Given that the Supreme Court does not seem like it will be turning the clock back on its Establishment

12. See McCreary County v. ACLU, 545 U.S. 844, 901-02 (2005) (Scalia, J., dissenting); see also, e.g., Am. Legion v. Am. Humanist Ass'n., 139 S. Ct. 2067, 2074 (2019); Town of Greece, 572 U.S. at 591-92.

13. See WEXLER, supra note 1, at 162-66.

14. See id. at 162-65.

15. See id. at 165-66. 
Clause jurisprudence any time soon, religious minorities are right to recognize that creation of a robust religious and nonreligious public pluralism is the best current option in a world of few other opportunities.

Such pluralism, however, requires that the courts continue to recognize the dangers of discrimination. The saving grace of the current Supreme Court's Establishment Clause jurisprudence has been its fairly consistent embrace of the notion that while the government can support religion in all sorts of ways, it cannot formally discriminate in its allocation of public goods among recipients based on the content of their religious or nonreligious commitments. As the Court famously stated in its 1982 decision of Larson v. Valente, "[t]he clearest command of the Establishment Clause is that one religious denomination cannot be officially preferred over another."16 As long as this principle remains ascendant, the possibility of a religiously cacophonous public square continues to exist-Christians can access government money, property, and institutions, but so can non-Christians. Christians can put up monuments on public property opened up to private speech, but so can Hindus, Taoists, and Zoroastrians, if they so choose. Christian schools and organizations can use public money to further their missions, but so can Krishnas, Muslims, and Satanists. Christians can start after-school clubs to promote their beliefs in public elementary and secondary schools, but so can Jews, Buddhists, and Confucians. Christians can give invocations before town board meetings, but so can Wiccans, Sikhs, and Rastafarians.

For this pluralism to be anywhere near adequate, however, government resources must be equally available to nonreligious individuals and organizations, fully authorized to articulate nonreligious perspectives on questions typically addressed by religion. In other words, a pluralism in which the only belief systems accorded the same treatment as Christianity are those that believe in some sort of divine being or have some other hallmark of traditional religion is a partial pluralism at best. Nonreligious belief systems such as Ethical Culture or Secular Humanism seek to answer the same questions that religious belief systems address - what is the ultimate meaning of life, how are human beings related to the rest of the cosmos, what constitutes ethical human action, how can human beings find community, etc.? A

16. Larson v. Valente, 456 U.S. 228, 244 (1982). 
public square that excludes these nonreligious alternatives to understanding fundamental issues relating to the place of human beings (among others) in the universe would be one that arbitrarily excludes the views of a substantial portion of the American population. After all, although statistics like these are always rightfully subject to legitimate quibbling at the margins, the data show that somewhere around twenty-five percent of the population of the United States describe themselves as not believing in any religious belief system whatsoever. 17

Thus, to return to my examples, if we really care about religious pluralism, and monuments to Christ and Buddha and Satan can stand on public property opened to private speech, then a monument to Ethical Culture must be allowed as well. If Buddhist and Christian and Hindu student groups can meet in public school classrooms after the school day is over to promulgate their beliefs, then secular groups must have the same courtesy. If Scientologists and Krishnas and Christians can receive government funding for their social service organizations, then Humanist groups must be able to apply for the same funding sources. And if Wiccans, Muslims, and Christians can give invocations before town board meetings, then Atheists must be allowed to the same. Moreover, they must be allowed to freely express their nonreligious beliefs in as "sectarian" a manner as anybody else.

On this score, there is both good news and bad news. The major good news is that, with respect to three of the four contexts I am describing-putting up displays and monuments, applying for government funding, and creating after-school programming-the bedrock First Amendment free speech principle that the government may not discriminate against speakers on the basis of viewpoint has, for the most part, resulted in the government formally treating Atheists and other secularists equally with religious believers. 18 True, many attempts by secularists to take advantage of these opportunities have been met with hostility from government actors and dissenting individuals (Our Non-Christian Nation catalogs many of these incidents, including Atheist displays being torn down and school officials discouraging secular students

17. See WEXLER, supra note 1 , at 6 .

18. See WEXLER, supra note 1, at 44-49, 120-21, 149-51; see also Wallace v. Jaffree, 472 U.S. 38, 52-54 (1985). 
from starting their own organizations ${ }^{19}$ ), but at least the law on the books protects the rights of those who describe themselves as nonreligious on an equal basis with religious believers. 20

The other bit of good news has to do with secular invocations. Not long after Justice Kennedy made clear in Town of Greece that government units sponsoring invocations must "maintain[] a policy of nondiscrimination,"21 Atheists and other secularists, both individually and in connection with organizations like Americans United for Separation of Church and State, the Freedom from Religion Foundation, and the Central Florida Freethought Community, began asking to give their own invocations before town meetings and were invited to do so by cities and towns and states across the country. ${ }^{22}$ Nobody knows for sure how many secular invocations have been offered nationwide, but the number is likely somewhere between one hundred and two hundred.23 Some of these secular invocations caused controversy, of course, but many of them proceeded without incident. 24 Invocations are particularly useful from the perspective of religious pluralism because they allow the speaker to talk about their deeply held beliefs to a basically captive audience of mostly politically active local citizens. ${ }^{25}$ An invocation, as we will see, can essentially serve as a short lesson about the content of a belief system as well as demonstrate to a perhaps ignorant audience that those who hold such beliefs are themselves responsible and thoughtful members of the community. 26 This is at least as true for secularists as it is for those who believe in traditional religions. Perhaps nothing better has come from the Court's line of separation-eroding church-state decisions than the upsurge of invocations given by religious minorities, including secularists.

19. See WEXLER, supra note 1 , at $47-48,149$.

20. See id. at 7 .

21. Town of Greece v. Galloway, 572 U.S 565, 585 (2014).

22. See infra notes 73-105 and accompanying text.

23. See infra note 87 and accompanying text.

24. See infra notes 99-103 and accompanying text.

25. For some examples of secular invocations, see infra notes 92-96 and accompanying text.

26. See infra notes 95-96 and accompanying text. 
Alas, this is where the distressing news comes in. In response to the increasing demand for secular invocations, several jurisdictions-Brevard County, Florida; the Pennsylvania House of Representatives; and the United States House of Representatives, most prominently-have declared their invocation practices offlimits to nonbelievers. 27 In each case, secularists, supported by separationist legal groups, challenged these policies in the courts as violations of their First Amendment rights and, in particular, the part of Town of Greece prohibiting the government from discriminating when it selects who will give invocations before public meetings. 28 All three cases were ultimately decided by federal circuit courts, with the government winning two out of the three disputes. 29

Specifically, challengers won in Florida but lost in both the Pennsylvania and the United States Houses of Representatives. In Williamson v. Brevard County, the Eleventh Circuit Court of Appeals avoided the question of whether the government can solely exclude secularists from its invocation programs based on its finding that the county board had in fact discriminated against a wide variety of minority religious faiths when selecting prayergivers. ${ }^{30}$ In Fields $v$. Speaker of the Pennsylvania House of Representatives, a split panel of the Third Circuit held that the Pennsylvania House was within its rights to exclude Atheists from its invocation program given that one of the primary purposes of its invocations was to ask for "divine guidance." 31 And in Barker $v$. Conroy, the D.C. Circuit, in an opinion by supposedly-liberal legallion David Tatel, summarily upheld the U.S. House of Representatives' policy of excluding secular invocations by pointing to the historical tradition of legislative prayer in the United

27. See infra notes Section III.A.; see also Williamson v. Brevard County, 928 F.3d 1296, 1298 (11th Cir. 2019); Fields v. Speaker of Pa. H.R., 936 F.3d 142, 146 (3d Cir. 2019); Barker v. Conroy, 921 F.3d 1118, 1121 (D.C. Cir. 2019).

28. Williamson, 928 F.3d at 1298; Fields, 936 F.3d at 147; Barker, 921 F.3d at 1121.

29. Williamson, 928 F.3d at 1317; Fields, 936 F.3d at 163; Barker, 921 F.3d at $1131-32$.

30. See Williamson, 928 F.3d at 1316.

31. Fields, 936 F.3d at 147. 
States, 32 which, true enough, has likely not included many secular prayers.

In this Article, I will argue that the decisions of the Third and D.C. Circuits are poorly reasoned, violate the basic First Amendment principle that the government may not discriminate on the basis of religion or viewpoint, wrongly sidestep the Supreme Court's admonition in Town of Greece that legislative prayer practices must be nondiscriminatory, and threaten to substantially undermine the religious pluralism that is the only real advantage to the Court's recent pro-religion Establishment Clause jurisprudence. While the Court's references in Town of Greece to non-discrimination norms are far from fully developed or crystal clear in their import, the best reading of them suggests that they constitute an additional requirement beyond whatever might be justified by the nation's historical practices regarding invocations before public meetings. The requirement of non-discrimination incorporates the basic, modern First Amendment principles that the government may not discriminate amongst religions or between religion and non-religion and that it may not discriminate on the basis of viewpoint when allocating public resources such as the opportunity to speak before government bodies. ${ }^{33}$ A practice that fits within our historical tradition of legislative prayer but fails the non-discrimination requirement should be held unconstitutional.

Of course, the government need not provide everyone who wants to speak before a public meeting an opportunity to do so, regardless of what they might say; in other words, nobody has the right to give an invocation about their favorite football team or the state of their marriage or even necessarily about the importance of a pristine environment. Under ordinary principles of First Amendment law as it applies in designated public forums, the government may limit the subject matter of invocations even if it may not exclude speech because of its viewpoint.34 Fleshing out this requirement, I argue for the following approach: Subject to certain content-neutral requirements (regarding timing, for example, or even perhaps the speaker's geographical connection to the relevant government body), the government must treat as

32. Barker, 921 F.3d at 1131.

33. Town of Greece v. Galloway, 572 U.S. 565, 585-88 (2014).

34. See Rosenberger v. Rector and Visitors of Univ. of Va., 515 U.S. 819, 829-30 (1995). 
equals, for purposes of determining who may give an invocation, any person who purports to speak on behalf of a belief system that would violate the Establishment Clause if it were put forward by the government as truth. 35 Since the government would violate the Establishment Clause just as surely by proclaiming that there is no god as it would if it proclaimed that Jesus is the son of God or that Thetans must clear the planet, then it follows that the government may not exclude those speaking on behalf of Atheist organizations from giving invocations before public meetings.

The Article proceeds as follows: In Part I, I describe briefly the Supreme Court's two decisions on legislative prayer, Marsh $v$. Chambers and Town of Greece v. Galloway, and argue that the insistence in those cases that the government maintain a policy of non-discrimination when implementing pre-meeting prayer practices constitutes an additional obligation beyond the requirement that the practice falls within the nation's historical traditions. In Part II, I describe the response of religious minorities to Town of Greece, focusing specifically on the coordinated movement among Atheists and others to offer secular invocations before government bodies across the country, including in some surprising conservative southern locales. By looking at some specific examples of secular invocations given in the past few years, I argue that the secular invocation represents a unique opportunity to promote religious pluralism in the United States by allowing secularists to explain their beliefs before captive audiences of politically-active citizens. I argue that government bodies should allow-indeed, should welcome, even solicit—secular invocations as a way of furthering religious pluralism. In Part III, I turn to the courts and the First Amendment. Section A of that Part describes the three judicial decisions on the issue of whether excluding Atheists from invocation practices violates the First Amendment. Section B of that Part critiques the decisions of the D.C. and Third Circuits and then offers a practical test for determining the proper set of possible invocation-givers within which courts should enforce the non-discrimination requirement of Town of Greece-a set that must include secularists.

35. See Geoffrey R. Stone, Content-Neutral Restrictions, 54 U. CHI. L. REV. 46, 48-51 (1987). 


\section{The Supreme Court And Legislative Prayer}

The Supreme Court has decided two cases about the constitutionality of starting government meetings with a prayer or invocation-Marsh v. Chambers in 1983,36 and Town of Greece $v$. Galloway in 2014.37 The issue in Marsh was whether the Nebraska legislature's practice of starting every session off with a prayer offered by its publicly-funded Presbyterian chaplain, Robert Palmer, violated the First Amendment. 38 In a six-three decision authored by Chief Justice Burger, the Court upheld the Nebraska House's practice. 39 The decision was thinly reasoned and failed entirely to grapple with any of the potential harms of legislative prayer that Justices Brennan and Stevens identified in their dissents.40 Instead, Burger rested his conclusion of constitutionality simply on the grounds that the Nebraska House's practice fit comfortably within the nation's historical tradition of legislative prayer. 41 Noting that the same Congress that drafted the Bill of Rights, including the First Amendment, had just days earlier passed a statute authorizing payment for House and Senate chaplains, the majority opinion concluded that, "[c]learly the men who wrote the First Amendment Religion Clauses did not view paid legislative chaplains and opening prayers as a violation of that Amendment." 42 The key language in the decision reads as follows:

The opening of sessions of legislative and other deliberative public bodies with prayer is deeply embedded in the history and tradition of this country. From colonial times through the founding of the Republic and ever since, the practice of legislative prayer has coexisted with the principles of disestablishment and religious freedom. . . .

$$
\cdots
$$

36. Marsh v. Chambers, 463 U.S. 783, 784 (1983).

37. Town of Greece v. Galloway, 572 U.S. 565, 569-70 (2014).

38. Marsh, 463 U.S. at 784-85.

39. Id. at 795 .

40. See id. at 795-98 (Brennan, J., dissenting); see id. at 822-24 (Stevens, J., dissenting).

41. Id. at 790, 793 (majority opinion).

42. Id. at 788 . 
In light of the unambiguous and unbroken history of more than 200 years, there can be no doubt that the practice of opening legislative sessions with prayer has become part of the fabric of our society. To invoke Divine guidance on a public body entrusted with making the laws is not, in these circumstances, an "establishment" of religion or a step toward establishment; it is simply a tolerable acknowledgement of beliefs widely held among the people of this country. 43

The primary holding of the case, then, is that, in general, legislative prayers do not violate the Establishment Clause because legislatures in the United States, both at the national and state levels, have started their sessions with prayers throughout the country's history, reaching back to even before the final language of the Establishment Clause was finished. 44 But that is not the only point of law contained in the opinion. In the brief, four-paragraph third section of the opinion, the Court also rejected claims that particular aspects of the Nebraska practice violated the Establishment Clause, including the fact that Palmer had occupied the chaplain's office for sixteen years and that his prayers were "Judeo-Christian" in nature. 45 The seeds of understanding Town of Greece's non-discrimination requirement can be found in the Court's answer to these arguments.

As to the first of these objections, the Court found that the selection of a single person was acceptable because it did not "advanc[e] the beliefs of a particular church" 46 and because there was no proof that his continued selection had "stemmed from an impermissible motive." 47 Rather, the Court found Palmer had been "reappointed because his performance and personal qualities were acceptable to the body appointing him." 48 The Court's assertion that choosing one person from one denomination to be the chaplain for sixteen straight years does not advance that denomination is of course quite ludicrous, but the important doctrinal point is that the

43. Id. at 786,792 .

44. See id. at 787-89.

45. Id. at $792-95$.

46. Id. at 793 .

47. Id.

48. Id. 
Court seems to have added here a new requirement for legislative prayer-it must not "advance[] the beliefs of a particular church." 49 By inference, if the Court had found that the practice in Nebraska had "advance[d] the beliefs of a particular church," presumably because of some "impermissible motive" of the legislature, then the practice would have violated the Establishment Clause.50 In response to the challenger's objection to the "Judeo-Christian" nature of Palmer's prayers, the Court said that "[t]he content of the prayer is not of concern to judges where, as here, there is no indication that the prayer opportunity has been exploited to proselytize or advance any one, or to disparage any other, faith or belief." 51 This suggests that not only must a legislative prayer practice (1) not advance a belief or church, but it also must (2) not proselytize, and (3) not disparage any faith or belief.

Almost everything about these requirements is a mystery. With regard to their content-what counts as advancement or proselytization or disparagement-the only thing we know from Marsh is that appointment of one chaplain for sixteen years does not constitute "advancing" a belief. We certainly do not know why that is true. Beyond the content, though, the legal source of the requirements is also unclear. The Court provides no illuminating citations and no explanation.52 One possibility, of course, is that they come from the historical practice itself. In other words, perhaps the reasoning is that the historical practice of legislative prayer, in its entirety, over nearly two-hundred years, has consistently not advanced, proselytized, or disparaged any faith, belief, or church and that therefore, to fit into that tradition, a contemporary prayer practice must not do any of those things either. But the Court made no effort whatsoever to demonstrate that the historical practice failed to do those things, and indeed it did not even assert such a conclusion. It seems likely that in some ways, in some times and places, the practice of legislative prayer certainly did do some of those things, at least to some degree.

The better way to read this part of Marsh is that the requirement of non-advancement/proselytization/disparagement is

49. Id.

50. Id. at 793-94.

51. Id. at 794-95.

52. Id. at 793 . 
an independent requirement beyond the mere "consistent with historic practice" criteria that justifies legislative prayer under the Establishment Clause in the first instance. Not only did the Court make no attempt to ground the requirements in the historical practice itself, but the requirements are consistent with general Religion Clause jurisprudence outside the legislative prayer context. Even by 1983, the Court had set out the general rules that the government may not advance or inhibit or endorse or disapprove of religion, and although the Court in Marsh notoriously refused to apply the Lemon test to the practice of legislative prayer, the requirements of non-advancement and non-disparagement are closely aligned with that test. 53

In Town of Greece, the divided Court applied Marsh to uphold a northern New York town's practice of starting its board meetings off with a prayer.54 The practice differed from the practice in Marsh in several key ways-the prayers were given by guest speakers rather than an official chaplain; they were fully sectarian in the sense that they regularly and substantially referred to specific aspects of the Christian faith (in Marsh, Chaplain Palmer had stopped referring to Christ after a Jewish legislator complained55); and they were given in the context of a town meeting, attended by members of the community, some of whom at any given meeting might have had business before the board, rather than before a legislative body. 56 Five Justices held that none of these differences rendered Greece's practice unconstitutional, resting their decision largely on a straightforward application of Marsh, which Justice Kennedy described "stands for the proposition that it is not necessary to define the precise boundary of the Establishment Clause where history shows that the specific practice is permitted."57 At the same time, however, the Court made it clear that "Marsh must not be understood as permitting a practice that

53. See id. at 792-95; see also Lemon v. Kurtzman, 403 U.S. 602, 612-13 (1971) (articulating what would be known as the Lemon test as: "First, the statute must have a secular legislative purpose; second, its principal or primary effect must be one that neither advances nor inhibits religion; finally, the statute must not foster 'an excessive government entanglement with religion." (citations omitted)).

54. See Town of Greece v. Galloway, 572 U.S. 565, 591-92 (2014).

55. Marsh, 463 U.S. at 793 n.14.

56. For the facts of the case, see Town of Greece, 572 U.S. at 570-72.

57. Id. at 577 . 
would amount to a constitutional violation if not for its historical foundation." 58

Specifically, as to the sectarian nature of the prayers in Town of Greece, the Court observed that such explicitly sectarian language had been common at the time of the framing of the Establishment Clause and thus fit within the relevant historic tradition. "The Congress that drafted the First Amendment[,]" Justice Kennedy wrote, "would have been accustomed to invocations containing explicitly religious themes of the sort respondents find objectionable."59 As in Marsh, however, the Court did not end its analysis with history alone. Reiterating Marsh's point that the content of legislative prayers is irrelevant absent an "indication that the prayer opportunity has been exploited to proselytize or advance any one, or to disparage any other, faith or belief," 60 the Court this time around provided some details about what might constitute advancement, disparagement, or proselytization:

In rejecting the suggestion that legislative prayer must be nonsectarian, the Court does not imply that no constraints remain on its content. The relevant constraint derives from its place at the opening of legislative sessions, where it is meant to lend gravity to the occasion and reflect values long part of the Nation's heritage. Prayer that is solemn and respectful in tone, that invites lawmakers to reflect upon shared ideals and common ends before they embark on the fractious business of governing, serves that legitimate function. If the course and practice over time shows that the invocations denigrate nonbelievers or religious minorities, threaten damnation, or preach conversion, many present may consider the prayer to fall short of the desire to elevate the purpose of the occasion and to unite lawmakers in their common effort. That circumstance would present a different case than the one presently before the Court. 61

\footnotetext{
58. Id. at 576 .

59. Id. at 578 .

60. Id. at 581 .

61. Id. at 582-83.
} 
This passage further underscores that general conformity with historical tradition is necessary but not sufficient to uphold any given legislative prayer practice. The requirement that the prayer practice also fails to advance, denigrate, or proselytize is an independent one that is derived not from historical practiceindeed, as in Marsh, the Court in Greece does not assert, much less make any effort to support, the notion that the historical practice failed to do any of these things-but rather from the current purposes of legislative prayer in the modern day, which the Court identified as lending gravity to the occasion and reflecting historical values (which of course may not have always been realized) of "shared ideals and common ends."62 Read together with the Court's earlier observation that "Marsh must not be understood as permitting a practice that would amount to a constitutional violation if not for its historical foundation,"63 this passage makes it fairly clear that legislative prayer practices are subject to constitutional requirements beyond simply being generally aligned with the nation's historical practice.

Further support for this reading of Town of Greece comes from Justice Kennedy's treatment of the plaintiffs' argument that town board prayers are unconstitutionally coercive in a way that legislative prayers are not. In rejecting this argument, Justice Kennedy, writing only for himself, the Chief Justice, and Justice Alito, clearly recognized that a prayer practice may not coerce attendees into participating in the prayer.64 This requirement, however, was not drawn from any historical tradition, but rather from an independent constitutional source, specifically the "elemental First Amendment principle that government may not coerce its citizens 'to support or participate in any religion or its exercise."65 Justice Kennedy found, based on the facts in the record, that Greece had not "compelled its citizens to engage in a religious observance," 66 but he further observed that "[t]he analysis would be different if town board members directed the public to participate in the prayers, singled out dissidents for opprobrium, or

62. Id. at 583 .

63. Id. at 576 .

64. Id. at 591 .

65. Id. at 586 (quoting County of Allegheny v. ACLU, 492 U.S. 573, 659

(1989) (Kennedy, J., concurring in judgment in part and dissenting in part)).

66. Id. at 587 . 
indicated that their decisions might be influenced by a person's acquiescence in the prayer opportunity."67 Again, Justice Kennedy made no attempt whatsoever to argue that the historical tradition of town board prayers had been consistently non-coercive in these ways (indeed, the opinion's sole reference to the purported historical tradition of local government prayer consists of one report of one city council's proceedings from 191068), thus further lending support to the argument that avoiding coercion is a constitutional requirement independent of and additional to general conformity with historical tradition.

Thus far, then, Marsh and Town of Greece appear to hold that (1) the government may engage in a practice of starting sessions off with a prayer without violating the Establishment Clause if the practice generally fits within the historical tradition of such prayers in the United States, so long as (2) the practice does not advance a religious belief, denigrate non-believers or minorities, or proselytize/preach conversion, and (3) the practice does not coerce nonbelievers into participating in the prayer. Requirements two and three seem to have their source in fairly noncontroversial readings of the First Amendment and are to be measured independently of any historical tradition.

The final doctrinal piece of Town of Greece is its requirement of nondiscrimination, which should be understood in the same way as the requirements of non-advancement, non-disparagement, nonproselytization, and non-coercion-in other words, as an independent constitutional obligation. In response to the argument that "the town of Greece contravened the Establishment Clause by inviting a predominantly Christian set of ministers to lead the prayer,"69 the Court was satisfied that the town had both made "reasonable efforts" to identify the religious organizations within its borders and had indicated it would "welcome a prayer by any minister or layman who wished to give one.”70 Justice Kennedy concluded that: "[s]o long as the town maintains a policy of nondiscrimination, the Constitution does not require it to search beyond its borders for non-Christian prayer givers in an effort to

67. Id. at 588 .

68. Id. at 576 .

69. Id. at 585 .

70. Id. 
achieve religious balancing."71 Of course, Justice Kennedy did not expound on what precisely this nondiscrimination requirement entails or where it comes from, but this failure to specify is understandable if the requirement simply represents the obvious First Amendment mandate that the government may not prefer one belief system over any other belief system and may not discriminate on the basis of viewpoint in any type of government forum. The Court might very well have introduced this nondiscrimination requirement in the same way it introduced its non-coercion requirement, namely as "an elemental First Amendment principle."72 That is certainly how many of the nation's secular individuals and organizations understood it, as detailed in the next Part.

\section{SeCUlar InVOCATiOns AFTER TOWN OF GREECE}

Although secularists had given invocations before public bodies prior to the Court's decision in Town of Greece, 73 it was that decision, and specifically Justice Kennedy's observation about nondiscrimination, that sparked a substantial increase in the number of secular invocations that have been given before legislatures and town boards across the nation. Much of this increase can be attributed to the concentrated efforts of a small number of influential secularist and separationist organizations, such as Americans United for Separation of Church and State (Americans United), the American Humanist Association (AHA), the Freedom from Religion Foundation (FFRF), and the Central Florida Freethought Community (CFFC), all of which pounced on the Court's anti-discrimination language to start campaigns aimed at ensuring and increasing diversity and pluralism in the country's prayer practices.

As part of its "Operation Inclusion" program, for example, Americans United developed legal guidelines for what is and is not allowed under Town of Greece, drafted a model secular invocation

71. Id. at $585-86$.

72. Id. at 586 .

73. See, e.g., Invocations from Other Areas, Cent. Fla. Freethought CMTY., https://www.cflfreethought.org/invocations [perma.cc/JY4Y-YQSZ] (last visited Feb. 8, 2021) (collecting links to invocations both after and before Town of Greece). According to this source, secular invocations had been given very occasionally before Town of Greece was decided in 2014, going back at least until 2004. Id. 
for members and other nonbelievers to use for their own invocations, and actively began monitoring the practices of localities to ensure that minorities were being treated fairly and equally.74 The Operation Inclusion webpage clearly links these efforts to the Court's decision in Town of Greece, noting that:

The [Town of Greece] ruling was a bad decision, but the Court did make it clear that the First Amendment imposes limits on local governments that open their meetings with ceremonial prayers. Towns cannot discriminate on the basis of religion; town leaders cannot lead others in prayers or integrate worship into the legislative process; and invocations cannot proselytize or denigrate other belief systems. 75

A key part of Operation Inclusion focuses on mobilizing members to become actively involved in making sure that if a town or other locality does maintain a prayer practice, it does so consistent with the Court's anti-discrimination mandate:

Operation Inclusion is an initiative to . . MOBILIZE our chapters across the country, as well as independent activists, to certify that the rules are being followed and that minority perspectives-especially non-Christian and non-theist viewpoints - are not discriminated against. We will equip people to approach their local boards and councils to request the opportunity to offer an opening message that is inclusive and stresses the importance of church-state separation. We will establish a vehicle for activists and other citizens to report back to us when municipalities discriminate against would-be speakers or violate the spirit or principles of the Supreme Court's decision by not including everyone. 76

74. See Operation Inclusion, AMs. United For SEPARATION OF CHURCH AND STATE, https://www.au.org/content/operation-inclusion [perma.cc/ZR23-SAL3] (last visited Feb. 8, 2021).

75. Id.

76. Id. 
The AHA, for its part, launched its secular invocation program the very same day that the Court announced Town of Greece. 77 In its May 5, 2014, press release, the AHA observed that:

The Supreme Court's ruling, authored by Justice Kennedy, makes clear that local governments must make "reasonable efforts to identify all of the congregations located within its borders" and welcome an invocation by anyone who wishes to give one, regardless of their faith. The majority decision also states that the policy must be one of nondiscrimination. 78

The program, known as "The Humanist Society," allows individuals to apply for approval as "Humanist Invocators," and includes an interactive map to help Humanists identify people in their areas who would be willing and able to give nonreligious invocations. 79 Also in 2014, FFRF created its "Nothing Fails Like Prayer" competition to award five-hundred dollar prizes for the year's best secular invocations. 80 The prizes have been awarded every year since and FFRF explicitly intends them to "be a Paine in the government's Mass—a Thomas Paine." 81

Perhaps no organization has had as much of an impact on spreading the practice of secular invocations than the CFFC, a chapter of FFRF headquartered in the Orlando area. Led by activist David Williamson, the CFFC engages in a wide variety of secularist activities, educating members and non-members alike about the law surrounding state-sponsored religion and serving as a watchdog group in communities that often cross constitutional

77. See Humanist Group Launches Secular Invocations Program in Response to Supreme Court's Ruling, AM. HuMANIST Ass'N, https://americanhumanist.org/news/2014-05-humanist-group-launches-secular-invocations-program/ [perma.cc/UC5S-GQVJ] (last visited Feb. 8, 2021).

78. Id.

79. See Humanist Invocations, The Humanist Soc'Y, www.thehumanistsociety.org/invocations [perma.cc/UD8S-J8YV] (last visited Feb. 8, 2021).

80. 'Nothing Fails Like Prayer' contest, FREEDOM FROM RELIGION Found., https://ffrf.org/outreach/nothing-fails-like-prayer [https://perma.cc/8S4FERHY] (last visited Feb. 8, 2021).

81. Id. 
lines. 82 With respect to invocations, the group says this on their website:

We maintain that religious prayer has no place at local government meetings since members of the public attend and participate. However, in light of the May, 2014 Supreme Court decision in Town of Greece v. Galloway, the best possible action we can take is to ensure that all venues include diverse perspectives. This includes providing opportunities for all faith traditions and non-believers seeking the opportunity to participate and ensuring that no pattern of prayer exists which denigrates, proselytizes, or advances any one religion or disparages any other. 83

To this end, CFFC members have asked to give (and have given) secular invocations all over central Florida, in conservative locales like Volusia, Lake, and Osceola counties. ${ }^{84}$ The group also keeps an invaluable running record of all the invocations that its members have given in central Florida, as well as many secular invocations given by others in different parts of the country. 85 The website lists and provides links to the text and/or videos for ninety invocations that members of the organization have given in central Florida and about forty given by others elsewhere in the country since the Town of Greece decision was handed down. 86

It is not clear exactly how many secular invocations have been given that are not catalogued on the CFFC website, but there are some, which suggests that the total number of secular invocations given in the United States since 2014 is at least somewhat higher than the one-hundred and thirty or so that are listed. 87 Humanists and other secularists have given invocations across the country, from Maine to Arizona, from Florida to Washington State. 88 Most of the invocations have taken place before local boards, from small towns like Shelbyville, Kentucky and Oskaloosa, Iowa to larger

82. See generally Cent. Fla. Freethought CMty., https://www.cflfreethought.org/ (last visited Feb. 8, 2021).

83. Cent. Fla. Freethought CMty., supra note 73.

84. See id.

85. See id.

86. See id.

87. See id.

88. See id. 
cities like New Orleans, Louisiana and Lubbock, Texas. 89 Some have been given before state legislative bodies, including the Arizona House of Representatives, the Iowa State House, and the Pennsylvania Senate, among others. 90 As I will discuss below, many of the invocations have gone smoothly, but by no means have all of them.

It is hard to generalize about the content of these secular invocations, but certain themes tend to repeat themselves. Many secular invocations begin by asking the audience specifically not to bow their heads but instead to look around at the people around them. Illustrative is the invocation given by Arizona Representative Athena Salman, who, in her April 18, 2017, speech before the Arizona House of Representatives, opened by saying: "Take a moment to look around you at the people gathered today. We come from a variety of backgrounds and interests, but the passion that ignites us; the fire that burns within us; is similar."91 Likewise, Humanist Luke Douglas started his invocation before the Scottsdale, Arizona, City Council meeting on January 14, 2020, with:

Rather than closing our eyes or bowing our heads, it is customary in a Humanist invocation to keep one's eyes open. Look around at your neighbors, your colleagues, your fellow Human beings. Humanists have no holy books, only the literature and philosophy of humans who have gone before, whose ideas stand or fall on their own merit. 92

The notion that people should start off a public meeting by looking around at one's fellow humans and citizens is consistent with another primary theme of many secular invocations-the importance of equality and inclusion. A perfect example of an

89. See id.

90. See id.

91. John Nichols, An Arizona Legislator Gave an Invocation That Didn't Mention God. You Won't Believe What Happened Next., The Nation (Apr. 21, 2017), https://www.thenation.com/article/archive/an-arizona-legislator-gavean-invocation-that-didnt-mention-god-you-wont-believe-what-happened-next/ [https://perma.cc/45BF-FHLP].

92. Hemant Mehta, Atheist Cites Lucifer in Invocation During Scottsdale (AZ) City Council Meeting, FrIEndly ATHeist (Jan. 17, 2020), https://friendlyatheist.patheos.com/2020/01/17/atheist-cites-lucifer-in-invocation-duringscottsdale-az-city-council-meeting/ [perma.cc/T8ZY-TRZF]. 
invocation that invokes inclusivity as a core value is the one given by Nick Lee, a member of the San Antonio chapter of Americans United, in September of 2018 before the San Antonio City Council:

This morning, I do not ask you to bow your heads in prayer. Rather, I draw your attention to the citizens who are gathered here today to do business with the city. They come from different economic circumstances and from ethnic backgrounds. Yet, they all hope to receive from you an equitable hearing of their concerns. And beyond this room, I ask you to remember all one-and-a-half million people whom you are collectively pledged to serve. Consider the diversity of cultures, economic interests and religious backgrounds which are represented in this community. In terms of religion, this includes not only the many varieties of Christians, but also Jews, Muslims, Hindus, Sikhs, atheists, and others .... These citizens of San Antonio look to each of you to apply wisdom, integrity, and rational thinking to the affairs of the city, and to treat all fairly and without favor. 93

A third, fairly common theme found among secular invocations is the importance and centrality of reason to the human condition, and specifically to the process of governing in a democratic society. An example comes from United Coalition of Reason member, Ed Sweeney, in his invocation before the Upper Arlington City Council Meeting in Ohio:

In this room, let us cherish and celebrate our shared humanness and capacity for reason. Let us celebrate our compassion for the people of our City; the love for our Constitution and our democracy. Reason has the power to solve even the most challenging problems, while cultivating intelligent, moral and ethical interactions

93. Rob Boston, Historic Invocation: For the First Time Ever, A San Antonio City Council Meeting Began With A Secular Reflection-And Americans United Activists Led the Way, Ams. United For SEPARATION OF CHURCH AND STATE (Nov. 2018), https://www.au.org/church-state/november-2018-churchstate/featured/historic-invocation-for-the-first-time-ever-a-san [https://perma.cc/T54K-RRK3]. 
among people of varying backgrounds and beliefs or nonbeliefs. 94

Another example can be found in CFFC member Joseph Richardson's invocation in Eustis, Florida, in May of 2017:

It is through reason that, more than 2,200 years ago, with nothing more than shadows and a little geometry, Eratosthenes was able to show that the Earth was indeed a sphere and calculate its circumference to within [one percent]. It is through reason that 300 years ago we began the Enlightenment and struggled our way out of the darkness and superstition of the Middle Ages. Through reason, Einstein made predictions about the cosmos that we are still confirming 100 years later. Through reason, we know that we are intimately connected, not only to every other human, but also to every living thing. Despite the advances of reason, we are all wrong about something. It is a continuous, life-long effort to be "less wrong" and to use new information and reason to achieve that goal. You have the opportunity to do that again tonight. You will receive new information and make decisions about that information. I urge you to exercise empathy to understand how your constituents feel, to use compassion to consider how your decisions will affect them, and to apply reason in the evaluation of all things. 95

As illustrated by the invocation's phrase, "we know that we are intimately connected, not only to every other human, but also to every living thing," another common theme found in secular invocations is the celebration of science, nature, and the relationship between human beings and nature. Consider, for example, Althena Salman's 2019 invocation before the Arizona House of Representatives:

94. Secular Invocation: Ed Sweeney, Freethought Today (June/July 2017), https://ffrf.org/publications/freethought-today/item/29695-secular-invocation-ed-sweeney [perma.cc/8LEX-A24X].

95. Hemant Mehta, An Atheists' Godless Invocation in Eustis (FL) is "Corrected” By a Commissioner's Christian Prayer, FRIEndLY ATHIEST (May 6, 2017), https://friendlyatheist.patheos.com/2017/05/06/an-atheists-godless-invocation-in-eustis-fl-is-corrected-by-a-commissioners-christian-prayer/ [perma.cc/3P36-LP3S]. 
Take a moment to reflect on the wonders of the universe. Bask in the awe and magnificence of the diversity of nature. Look upon the soaring mountains, the vast seas, the cloud-studded azure skies. Ponder how living things became so immensely diverse on our life-giving planet, how integrated and interdependent is all life meshed on our wondrous Earth. Can we truly fathom the depth of the intricacies required to produce and sustain living beings such as animals, plants, microbes, the engines that support the survival of such diverse lifeforms on an incredibly insignificant planet in an insignificant galaxy in an insignificant corner of an unimaginably immense universe that may possibly be a single speck floating in a sea of universes? The wonders of nature dwell deep in the hearts and minds of all people living on this wondrous rock we call Earth, as it makes its endless journey around a life-giving star we call sol. No matter what we may call it, we give thanks to the awe and inspiring power of nature itself. 96

Obviously, any person who delivers a secular invocation will have their own individual concerns and style and so the content of any given invocation will be unique to that individual, but the themes I have described over the past few pages-celebration of nature, reason, compassion, equality, and inclusivity-are without a doubt some of the more prominent themes found in these types of invocations. That should not be surprising, of course, since they are also some of the more prominent values held by secular organizations and their members generally.

Although legislative prayer is deeply problematic from the perspective of keeping religion and the government separate, it can-if managed correctly_provide some important social benefits. Specifically, allowing a diverse set of religious and nonreligious believers to address a political meeting can at least theoretically serve an important educative function. The speaker is given several minutes to speak about their core beliefs and values and how those values should be taken into account during the governing

96. Hemant Mehta, AZ Atheists Lawmaker Gives Invocation, Then Gets Mocked by Christian Colleague, FRIENDLY ATHIEST (Feb. 13, 2019), https://friendlyatheist.patheos.com/2019/02/13/az-atheist-lawmaker-gives-invocation-then-gets-mocked-by-christian-colleague/ [https://perma.cc/2CLBELSU]. 
process. The audience is largely captive and made up of both civic leaders and politically-engaged citizens. It is not hard to reimagine the pre-meeting invocation as a form of teaching. Not only can the invocation explain to the audience what, objectively, the speaker and their organization believe, but the speakers themselves can provide a model for the belief system that they represent. Imagine an attendee who knows very little about Hinduism, for instance, and perhaps has never met a Hindu person or heard one speak about their beliefs. By affording a Hindu speaker the opportunity to address the audience, the practice of legislative prayer allows the Hindu speaker to explain what Hindus believe and to provide a concrete example of a Hindu for the attendee to have in mind as he or she leaves the meeting to participate in a society that is becoming more and more diverse every day. Many people of all stripes have inaccurate and incomplete understandings of religious minorities and hold stereotypical views about their practitioners. Legislative prayer programs, assuming they include a diverse set of speakers, can help address this problem.

The last point, though, is the kicker. To perform their educative function, the programs must be diverse and include a pluralistic set of believers and nonbelievers to provide a full picture of society's religiosity. A prayer program in which every speaker is a Christian will be far less educative than one which involves a wide range of speakers. This is as true with respect to nonbelievers as it is with minority religious believers. A full religious education must include education about those who do not believe in any sort of god in addition to those who believe in all sorts of different gods. What do secularists believe? Can they be good without god? Are they outcasts? Dangerous? Do they want to destroy religion or co-exist with it? So many people in the United States identify as nonbelievers that there is no way to understand the nation's religious landscape without understanding what and how nonbelievers think. True religious pluralism must include nonreligious perspectives on the questions addressed by religion. It follows that to fulfill their educative potential, legislative prayer practices must include nonbelievers.

Thus, the silver lining in the cloud that is Town of Greece is Justice Kennedy's anti-discrimination warning. It is hardly surprising that so many minority religious and nonreligious individuals seized on Justice Kennedy's admonition to begin asking towns and other government bodies if they could participate in their 
legislative prayer programs. To the extent that those governmental bodies have allowed or invited a diverse set of speakers, including Atheists and other secularists, they should be applauded for promoting religious pluralism. Every governmental unit that starts its meetings off with an invocation should include-indeed, actively solicit—nonbelievers to participate in their program.

Given the benefits of pluralism, as well as the seeming universality of many secularist values, one might expect that most places would in fact allow secular invocations. And indeed, the typical secular invocation has given rise to little if no controversy. Most secular invocations have gone smoothly, as planned, with no vocal disapproval from the community. Indeed, when I spoke with David Williamson in 2015 about the CFFC's invocation program, he told me that he has encountered "very little opposition" to the group's efforts. One particular example of an invocation that proceeded without incident occurred in the Town of Greece itself, when, in October of 2015, atheist Linda Stephens, one of the two plaintiffs in the Town of Greece v. Galloway case, gave a secular invocation in front of the very town board that she had sued and brought all the way to the Supreme Court.97 As I recount in Our Non-Christian Nation, I visited the town and observed the invocation and can testify that, other than one guy next to me who took his hat off when the chairperson of the town board announced the opening prayer and then put the hat back on when it became clear there would be no actual "prayer," the invocation was received with politeness and respect. 98

On the other hand, there have been plenty of secular invocations that did not go nearly as smoothly as Stephens' talk before the Town of Greece board. Examples include the following:

- After Athena Salman's 2019 invocation before the Arizona House of Representatives, John Kavanaugh, a fellow Representative, ridiculed the invocation by saying: "I would like to introduce my guest: God. God is in the gallery, as He is everywhere. And the same God who, by the way, created nature, which

97. Linda Stephens, Freedom From Religion Found. (Oct. 20, 2015), https://ffrf.org/publications/brochures/item/25276-linda-stephens [https://perma.cc/63Z4-4B3A].

98. See WEXLER, supra note 1 , at 80-82. 
purportedly created this tiny speck of a planet in which this tiny speck of a legislature legislates." 99

- When Joseph Richardson, member of the CFFC, gave his secular invocation before a town commission meeting in Eustis, Florida, Commissioner Anthony Sabatini gave a Christian counter-invocation, calling upon the "Lord" to "give us the strength to live like your son Jesus Christ."100

- At a secular invocation in Lake Forest, Florida, in December, 2014, given by Atheist Preston Smith, four out of the five town commissioners, including the mayor, stood up and walked out of the room. 101

- When Aleta Ledendecker, member of the Rationalists of East Tennessee, gave an invocation in January of 2016 in front of the Oak Ridge City Council, one councilwoman skipped the invocation, and another one got up toward the end and walked out. The one who walked out-Rick Chinn-explained that he "couldn't take it anymore" because, in his opinion, "this country was founded on Christian principles." 102

- After Athena Salman's April 2017 invocation before the Arizona House of Representatives, some Republicans expressed offense, including Majority Leader John Allen, who explained that invocations "must invoke a higher power" and that "if you don't want to pray, don't sign up for the prayer." 103

As described earlier, in the Introduction to the Article, several jurisdictions-specifically, Brevard County, Florida; the Pennsylvania House of Representatives; and the United States

99. Mehta, supra note 96.

100. Mehta, supra note 96.

101. Chris Joseph, Lake Worth Commissioners Walk Out During Atheist Invocation, BROWARD/PALM BEACH NEW TIMES (Dec. 9, 2014), https://www.browardpalmbeach.com/news/lake-worth-commissioners-walkout-during-atheist-invocation-6463464 [https://perma.cc/MJ7C-MS9S].

102. Bob Fowler, Oak Ridge council members boycott secular invocation, KNOXVILle News Sentinel (Jan. 12, 2016), http://archive.knoxnews.com/news/local/oak-ridge-council-members-boycott-secularinvocation-292a2603-fd33-41bf-e053-0100007f1793-365065171.html/ [perma.cc/93RL-V9JW].

103. Mehta, supra note 96. 
House of Representatives-have gone even further than simply objecting on principle to secular invocations by actually implementing legal bans on them.104 From the perspective of religious pluralism, this is a terrible mistake, for the reasons I explained earlier. But is it also unconstitutional? The constitutional propriety of these bans is the topic of the next Part.

III. The Constitutionality of Banning Secular InVocations

\section{A. The Cases}

\section{Williamson v. Brevard County}

The Board of County Commissioners of Brevard County (the Board) on the central east coast of Florida has long started its public meetings with a prayer. Four days after the Supreme Court decided Town of Greece, David Williamson, as the Chair of the CFFC, wrote a letter to the Chairwoman of the Board asking to give a secular invocation. 105 It took Williamson a second letter to get a response from the Board, and the response was negative.106 The Board told Williamson that he could address the Board during the "Public Comment" portion of the meeting (which takes place at the end) but could not give the opening invocation, because that was reserved for prayers invoking a higher power.107 After several other individuals asked to give secular invocations and several separationist organizations asked the Board to reconsider its exclusionary policy, the Board issued an eleven-page Resolution announcing its formal policy that only those who believe in a higher power may give the opening invocation at its meetings. 108 Secularists were allowed address the Board, but only in the Public Comment section at the end of the meeting. 109

Williamson and several other plaintiffs sued the Board in federal district court, claiming that the county's policy violated the

104. See Williamson v. Brevard County., 276 F. Supp. 3d 1260 (M.D. Fla. 2017); Fields v. Speaker of Pa. H.R., 251 F. Supp. 3d 772 (M.D. Pa. 2017); Barker v. Conroy, 282 F. Supp. 3d 346 (D.D.C. 2017).

105. Williamson, 276 F. Supp. 3d at 1266.

106. Id.

107. Id. at $1266-67$.

108. Id. at 1269 .

109. Id. at $1270-71$. 
Establishment Clause, as well as a number of other federal and state constitutional provisions.110 In a comprehensive opinion, District Court Judge John Antoon II found for the plaintiffs, finding that the exclusion of non-theists from the Board's prayer program contravened Town of Greece's anti-discrimination requirement as well as the Free Speech Clause's prohibition on viewpoint discrimination in a designated public forum.111 As part of the proceedings, the plaintiffs' lawyers deposed seven county commissioners and asked them questions about who could and could not offer opening invocations.112 Some of the answers ranged far beyond an interest in excluding Atheists and cast doubt on whether any non-monotheist would ever be allowed to give an invocation.113 For instance, several commissioners expressed uncertainty about whether Hindus, as polytheists, would be able to give invocations. 114 Same for Native American religions.115 Several commissioners said they would probably exclude Wiccans as well.116

On appeal, the Eleventh Circuit Court of Appeals affirmed, but the three-judge panel found the Board's invocation policy invalid on narrower grounds than the district court.117 In a unanimous opinion written by Judge Marcus, the court found the policy unconstitutional because, taken as a whole, the County Commission preferred certain religions over others.118 Part of this conclusion was based on the wording of the Resolution itself, which, in several places, explicitly expressed a preference for monotheistic invocations.119 For example, page two of the Resolution stated that, "[p]rior to the invocation, in recognition of the traditional positive role faith-based monotheistic religions have historically played in the community, the Board ... offer[s] the [presenting] cleric the

110. Id. at 1271.

111. Id. at 1299 .

112. Id. at 1279 .

113. Id. at 1279-80.

114. Id.

115. Id. at 1280.

116. Id. at 1279 .

117. See Williamson v. Brevard County, 928 F.3d 1298, 1310 (11th Cir. 2019).

118. See id. at 1299.

119. See id. at 1311-12. 
opportunity to tell the Board . . . about their religious organization." 120 Another portion of the Resolution, according to the court, expressed skepticism about any belief system that "espouse[s] or promote[s] reason . . . science . . . environmental factors [and] nature."121 "At the very least," wrote the court, "environmental factors' and 'nature' play a significant role in shaping some traditional Native American religions, not to mention some newer religions like Wicca."122

Beyond the language of the Resolution, the deposition testimony of the Commissioners dismayed, as it: "Reflect[ed] that the members put into practice the monotheistic preference endorsed in their written Resolution, and shows that members of the Board had no standards to apply, and minimal procedures to follow, as they invited speakers to give invocations." 123

On the basis of the Resolution's language and the deposition testimony, the court concluded that the Commissioners "have favored some religions over others, and barred those they did not approve of from being considered ... plainly violat[ing] the principle of denominational neutrality found at the heart of the Establishment Clause."124 The court remanded the case back to the district court with the expectation that the Commissioners would have a chance to "return to the drawing board and formulate new policies about how to begin the meetings." 125 As a result, the court did not specifically address the question of "whether the County is obliged to allow ... atheists and Secular Humanists . . . the opportunity to deliver an invocation at the start of one of its board meetings." 126

120. Williamson, 276 F. Supp. 3d at 1279 (quoting Brevard Coumty, Fla., Resolution 2015-101 (July 7, 2015) (emphasis in original)); see also Williamson, 928 F.3d at $1311-12$.

121. Williamson, 928 F.3d at 1312.

122. Id.

123. Id. at $1312-13$.

124. Id. at 1316.

125. Id.

126. Id. 


\section{Barker v. Conroy}

Although the U.S. House of Representatives has a permanent, paid Chaplain on staff to give a prayer at the beginning of each legislative session (currently the position is held by Father Patrick J. Conroy, a Catholic Priest127), since 1948 it has also employed a "guest chaplain" program to allow other individuals who are either invited by the Chaplain or sponsored by a member of the House to offer the opening invocation. 128 In 2015, Daniel Barker, an atheist and co-President of the FFRF, asked Father Conroy if he could give a secular invocation before the House.129 Conroy turned Barker down on the basis that anyone who gives an invocation before the House must address a "higher power."130 Hardly litigation shy, FFRF promptly sued, challenging the House's policy as a violation of the Establishment Clause and Equal Protection Clause, among other federal laws. 131

Both the district court judge (Judge Rosemary Collyer) and a three-judge panel of the D.C. Circuit Court of Appeals held in favor of the House. Judge Collyer's constitutional analysis took up a mere three pages of text and basically boiled down to the following three sentences:

Despite Mr. Barker's repeated attempts to characterize his claims as not challenging the constitutionality of legislative prayer, the reality is that his request to open the House with a secular invocation, which resulted in the denial of his request to serve as a guest chaplain, was a challenge to the ability of Congress to open with a prayer. To decide that Mr. Barker was discriminated against and should be permitted to address the House would be to disregard the Supreme Court precedent that permits legislative prayer. Marsh definitively found that legislative prayer does not violate the Establishment Clause. 132

127. Barker v. Conroy, 282 F. Supp. 3d 350, 350-51, 354 (D.D.C. 2017).

128. Id. at 351 .

129. Id.

130. Id.

131. Id. at $351-52$.

132. Id. at 364 . 
With liberal judges David Tatel and Harry Edwards assigned to the D.C. Circuit panel hearing the appeal in Barker v. Conroy (the third judge was conservative Judge Douglas Ginsburg), pluralists might be forgiven for being optimistic about the case.133 If so, though, they were disappointed by the decision, which gave short shrift to Barker's weighty claims, summarily affirming the district court in a few pages of thinly reasoned analysis.134 After reviewing Marsh and Town of Greece, Judge Tatel's opinion distilled a simple "two-step process for assessing the constitutionality of a particular legislative prayer practice: identify the essential characteristics of the practice and then determine whether that practice falls within the tradition the Supreme Court has recognized as consistent with the Establishment Clause."135 After identifying the "essential characteristic" at issue with the House's prayer practice as "limit[ing] the opening prayer to religious prayer," 136 the court then asked whether this "fit "within the tradition long followed in Congress and the state legislatures'?"137 “The answer," wrote the court, "is yes":138

Marsh and Town of Greece leave no doubt that the Supreme Court understands our nation's longstanding legislativeprayer tradition as one that, because of its 'unique history,' can be both religious and consistent with the Establishment Clause. . . . And although the Court has warned against discriminating among religions or tolerating a pattern of prayers that proselytize or disparage certain faiths or beliefs, it has never suggested that legislatures must allow secular as well as religious prayer. In the sui generis context of legislative prayer, then, the

133. See Mike Leonard, Atheist Loses Bid to Serve as U.S. House 'Guest Chaplin,' BlOOMBERG LAW (Apr. 19, 2019), https://news.bloomberglaw.com/uslaw-week/atheist-loses-bid-to-serve-as-house-guest-chaplain [https://perma.cc/F8PS-LJ5S].

134. See Barker v. Conroy, 921 F.3d 1118, 1131-32 (D.C. Cir. 2019).

135. Id. at $1129-30$.

136. Id. at 1130 .

137. Id.

138. Id. 
House does not violate the Establishment Clause by limiting its opening prayer to religious prayer. 139

This was pretty much the entirety of the court's reasoning.

3. Fields v. Speaker of the Pennsylvania House of Representatives

Like the U.S. House of Representatives, the Pennsylvania House also utilizes a guest chaplain program to allow non-members who are nominated by members to give the opening invocation. After several members of secular organizations requested the opportunity to "offer uplifting and inspirational messages" at the beginning of a House session, 140 the House responded by amending its internal rules to add House Rule 17: "[t]he Chaplain offering the prayer shall be a member of a regularly established church or religious organization or shall be a member of the House of Representatives." 141 The rejected secularists sued, challenging the exclusion of non-believers from the House's prayer practice as a violation of the Establishment Clause, among other constitutional provisions. 142 The defendants moved to dismiss the complaint under Rule 12(b)(6) of the Federal Rules of Civil Procedure for failure to state a claim upon which relief may be granted.143

In April 2017, Chief District Judge Christopher Conner issued an opinion denying in part defendants' motion to dismiss, finding that the plaintiffs had indeed stated a claim under the Establishment Clause.144 Reading Town of Greece's antidiscrimination mandate as an independent constitutional requirement, the court found that the plaintiffs had successfully pled a colorable case of discrimination:

Town of Greece installs a new metric in the legislative prayer analysis: when a legislature opens its door to guest chaplains and other prayer givers, it may not purposefully discriminate among them on the basis of religion. The

139. Id. at 1131.

140. Fields v. Speaker of the Pa. H.R., 251 F. Supp. 3d 772, 776 (M.D. Pa. 2017).

141. Id. at 777 (quoting Gen. Operating Rules of the Pa. H.R. r. 17).

142. Id. at 778 .

143. See id. at 778-79.

144. Id. at 792 . 
complaint articulates a plausible violation of this tenet. Plaintiffs allege that they are members of . . . minority religions, and that they have been purposefully excluded from the House's guest chaplain program on the basis of their beliefs. 145

The court further explained that the more difficult questions posed by the case-"whether history and tradition sanctify the House's line of demarcation between theistic and nontheistic chaplains," for instance- "demands, and deserves" the type of factual record that could only be developed beyond the 12(b)(6) stage. 146

Following discovery and the filing of cross-motions for summary judgment, Judge Conner issued an opinion in August of 2018 finding that the Pennsylvania House had violated the Establishment Clause by excluding atheist invocations. ${ }^{147}$ The court began its analysis by finding that nothing in the historical record demonstrated a tradition of explicitly excluding nonbelievers from giving invocations. "That history has tolerated the natural prevalence of theistic legislative prayer," Judge Conner wrote, "is hardly evidence that the Framers would abide deliberate and categorical exclusion of nontheists." 148 Further, the court observed that while Justice Kennedy's anti-discrimination language in Town of Greece might have technically been dicta, the admonition was nonetheless persuasive and consistent with the goal of protecting religious diversity, one of the key purposes of the Establishment Clause.149 After reviewing the district court decisions in Williamson and Barker and finding the former to be far more persuasive than the latter, 150 the court concluded its analysis by rejecting the House's argument that secular invocations cannot fulfill the purposes of legislative prayer, particularly the solicitation of "divine guidance for the benefit of the legislatures."151 Rather, the court explained, secular invocations, as evidenced by the many

145. Id. at 789 .

146. Id.

147. Fields v. Speaker of the Pa. H.R., 327 F. Supp. 3d 749, 766 (M.D. Pa. 2018).

148. Id. at 758 .

149. Id. at 759-60.

150. Id. at 761-63.

151. Id. at 763 . 
such invocations given in recent years, are fully capable of solemnizing the legislative process, lending gravity to the situation, and, as Justice O'Connor once put it, "encouraging the recognition of what is worthy of appreciation in society." 152

The secularist victory at the district court level in Fields was short-lived, however. In August of 2019, a divided Third Circuit Court of Appeals reversed the district court's decision. 153 The reasoning of the majority opinion, written by Judge Ambro, was quite similar to Judge Tatel's analysis in Barker but somewhat more thorough. The majority applied a historical framework and found that the exclusion of secularists was "historically sound" both because "only theistic prayer can satisfy all the traditional purposes of legislative prayer,"154 including "seek[ing] 'divine guidance' in lawmaking," 155 and because "the Supreme Court has long taken as given that prayer presumes invoking a higher power."156 The court conceded that atheism and other secular belief systems could be understood as "religious" by contemporary standards, but found the possibility to be beside the point because even if it were true, an atheist invocation still could not fulfill the "divine guidance" purpose of legislative prayer. 157 The court was careful to reject the House's position that it need only allow more than one sect to partake in the prayer context, noting, for example, that "our reasoning today could not be twisted to exclude Buddhists-an outcome we agree would be "unconscionable,"'158 but it did not think it necessary to extend the nondiscrimination mandate of Town of Greece to nontheists. 159 As a final point, the majority argued that a contrary result might cause "fringe" groups to seek to partake in the prayer practice, thus causing cities and towns to end their invocation programs altogether.160 "If, in the name of

152. Id. at 763 (citing Lynch v. Donnelly, 465 U.S. 668, 693 (O'Connor, J., concurring)).

153. Fields v. Speaker of the Pa. H.R., 936 F.3d 142 (3d Cir. 2019).

154. Id. at 147,150 .

155. Id. at 151 .

156. Id. at 150 .

157. Id. at $153-54$.

158. Id. at 155 .

159. Id. at $155-56$.

160. Id. at 157 . 
nondiscrimination, the House must abide prayers from nontheists, Satanists, and groups that deride religion," the court wrote, "it will stop accepting guest chaplains altogether ... result[ing] in less diversity of religious expression- $\mathbf{a}$ 'particularly perverse result."'161

Judge Restrepo wrote a substantial dissent.162 For him, the key historical inquiry was whether the express exclusion of nontheists was part of the historical practice of legislative prayer.163 The answer to that question, as Judge Restrepo put it, was "clearly "no"'164_indeed, it is clear from Senate and House documents issued in 1853, reviewing the prayer practices of both bodies, that the "history [of] legislative prayer never involved the purposeful exclusion of persons from consideration to serve as chaplains on the basis of their religions or religious beliefs."165 The dissent did not stop there, however. Moving on from his historical analysis and quoting Town of Greece's warning that "Marsh must not be understood as permitting a practice that would amount to a constitutional violation if not for its historical foundation,"166 Judge Restrepo argued that even if the House's practice was historically sound, it would still violate the Establishment Clause because it discriminated against nonbelievers. He emphasized:

By mandating that all guest chaplains profess a belief in a "higher power" or God, the Pennsylvania House fails to stay "neutral in matters of religious theory"; in effect, the Pennsylvania House "promote[s] one ... religious theory"belief in God or some sort of supreme deity- "against another"-the denial of the existence of such a deity. ${ }^{167}$

As I will argue in the next Section of this Part, Judge Restrepo's approach to the question of whether the government can exclude secularists from its invocation practices makes the most sense of any that the judiciary has put forward up until now.

161. Id.

162. See id. at 163-71 (Restrepo, J., dissenting).

163. Id. at 165 .

164. Id.

165. Id. at 166 .

166. Id. at 167-68 (quoting Town of Greece v. Galloway, 572 U.S. 565, 576 (2014)).

167. Id. at 168 . 


\section{B. Evaluating the Constitutionality of Secularist Exclusion Policies}

Two observations are worth making at the outset of figuring out how to apply Marsh and Town of Greece to the practice of excluding secularists from giving opening invocations, one that should be uncontroversial, the other somewhat more so. First, anyone trying to figure out how these cases should be applied to new situations has to recognize and concede that there will be no clear or obvious answers. In both cases, the Court announced one test (the historical practice test) without explaining in detail how to apply it, and then almost as an afterthought announced additional criteria (non-disparagement and nondiscrimination) without explaining what the criteria mean, how they should be applied, or even what the legal source or sources of the criteria are.168 By using such a minimalist approach to resolving the cases on the specific facts at issue, the Court has guaranteed that lower courts will rightly be confused about how to apply the cases, and commentators who argue that they should be applied one way or another should admit the same. Thus, the analysis I provide in the balance of the Article should be understood in that way-I will put forward what I believe is the best understanding of how Marsh and Town of Greece should be applied to atheist exclusion policies, but I am hardly claiming that this understanding is obvious or that other understandings are necessarily unreasonable.

The second observation-the one that is likely to be more controversial-is that Marsh, because of its highly anomalous approach and exceedingly thin reasoning, should be read as narrowly as possible. In the dissent he wrote for himself, Justice Marshall, joined by Justice Stevens and Justice Brennan, catalogued the various ways that legislative prayer infringes on the values represented by the Establishment Clause:

Legislative prayer clearly violates the principles of neutrality and separation that are embedded within the Establishment Clause . . . . It intrudes on the right of conscience by forcing some legislators either to participate in a "prayer opportunity" with which they are in basic disagreement, or to make their disagreement a matter of

168. See Marsh v. Chambers, 463 U.S. 783, 783 (1983); see also Town of Greece v. Galloway 572 U.S. 565, 585-88 (2014). 
public comment by declining to participate. It forces all residents of the State to support a religious exercise that may be contrary to their own beliefs. It requires the State to commit itself on fundamental theological issues. It has the potential for degrading religion by allowing a religious call to worship to be intermeshed with a secular call to order. And it injects religion into the political sphere by creating the potential that each and every selection of a chaplain, or consideration of a particular prayer, or even reconsideration of the practice itself, will provoke a political battle along religious lines and ultimately alienate some religiously identified group of citizens. 169

Justice Brennan then concluded with a line quite remarkable in the history of Religion Clause jurisprudence both for its truth and its candor: "I have no doubt that, if any group of law students were asked to apply [established principles] to the question of legislative prayer, they would nearly unanimously find the practice to be unconstitutional."170 To put it another way, although many difficult cases arise under the Establishment Clause, the case of legislative prayer is not one of them-it is clearly unconstitutional.

The majority opinion, strikingly, neither applied established principles, eschewing the application of the Lemon test or anything like it, nor addressed in any way Justice Brennan's various arguments against the practice of legislative prayer. ${ }^{171}$ Given the weakness of the opinion's reasoning, there is no good reason for it to be extended beyond its precise holding - that a legislature can begin its session with a prayer without violating the Establishment Clause.172 The resolution of other related or subsidiary questions need not replicate the original failures of Marsh through an unreflective extension of its core holding. Issues like the one I am discussing here should therefore not proceed through the routine application of the most anomalous and poorly reasoned Establishment Clause case in history, but rather through application of more generally accepted principles of the Establishment and Free Speech Clauses of the First Amendment.

169. Marsh, 463 U.S. at 808 (Brennan, J., dissenting).

170. Id. at 800-01.

171. See id. at 783-824.

172. Id. at 783 . 
With these observations, then, we can begin to evaluate the decisions of the Third and D.C. Circuits in Fields and Barker. As a first step, recall the reading of Marsh and Town of Greece set out earlier in Part I of the Article. According to that reading, those cases stand for the proposition that the government may engage in a practice of starting sessions off with a prayer without violating the Establishment Clause if the practice generally fits within the historical tradition of such prayers in the United States, so long as (1) the practice does not advance a religious belief, denigrate nonbelievers or minorities, or proselytize/preach conversion; (2) the practice does not coerce non-believers into participating in the prayer; and (3) the practice is non-discriminatory. 173

This approach differs significantly from Judge Tatel's framework in Barker $v$. Conroy, which basically included only one inquiry, divided into two steps: "identify the essential characteristics of the practice and then determine whether that practice falls within the tradition the Supreme Court has recognized as consistent with the Establishment Clause."174 The problem with this approach is several-fold. First, it ignores Town of Greece's warning that "Marsh must not be understood as permitting a practice that would amount to a constitutional violation if not for its historical foundation."175 An approach that asks solely whether the essential characteristics of a practice fall within historical tradition by its very terms would permit some practices that would in fact amount to constitutional violations. Examples of this constitute the second problem with Judge Tatel's approach, which is that it would allow clearly unconstitutional and undesirable practices-given that almost everyone who ever gave an invocation in the course of that historical practice was surely male, white, and Christian. Judge Tatel's approach would presumably allow a town or state to prohibit Black or Asian or Hispanic individuals from giving invocations or to exclude women from giving prayers or to limit those prayers to only Christian ones. Finally, Judge Tatel's framework leaves no room for the dicta of Marsh and Town of Greece concerning non-denigration, nondiscrimination, and non-proselytization; although that

173. See supra Part I.

174. See Barker v. Conroy, 921 F.3d 1118, 1129-30 (D.C. Cir. 2019).

175. Town of Greece v. Galloway, 572 U.S. 565, 576 (2014). 
language is dicta, it was clearly intended to be meaningful, and most courts that have looked at it have agreed.176

Applying the framework that I have suggested, then, the first question is whether exclusion of atheists fits within the historical tradition of legislative prayer. This question immediately leads to a second question: what exactly should we be looking for in the historical tradition to determine whether formal legal exclusion of secularists fits within that tradition? We know from the expert report filed in Fields, as well as the 1853 House and Senate Reports on Congressional prayer, that (1) secularist invocations were not in fact part of the historical tradition because they never actually occurred, and that (2) they were likely never formally excluded by law, as they have been in the Pennsylvania and U.S. Houses as well as in Brevard County. ${ }^{177}$ So, does this mean that formal legal exclusion of secular invocations fits or does not fit within the historical tradition? The dissent in Fields argues for the latter, finding that formal legal exclusion of secularists does not comport with the historical tradition.178 Judge Restrepo wrote: "[h]istory demonstrates that legislative prayer, as envisioned by the First Congress and as subsequently practiced by Congress since then, never involved the purposeful exclusion of persons from consideration to serve as chaplains on the basis of their religions or religious beliefs." 179

This is a strong argument, in my view, particularly if one accepts my position that Marsh should be read as narrowly as possible. The argument essentially says that unless discriminatory practices were explicitly written into the law during the historical period, then those practices cannot be used to justify current discrimination; it is a position that makes it more difficult rather than less difficult for the government to discriminate on the basis of religion and other essential characteristics, which is a result that seems self-evidently desirable. On the other hand, it is certainly possible that the Court intended its historical tradition test to be applied less formalistically and that the sole question really should be whether secular invocations were common during the historical

176. See Marsh, 463 U.S. at 794-95; Town of Greece, 572 U.S. at 585.

177. See Fields v. Speaker of the Pa. H.R., 936 F.3d 142, 165-66 (3d Cir. 2019) (Restrepo, J., dissenting).

178. See id. at 166.

179. Id. (emphasis in original). 
period. That is the view of Judge Tatel in Barker and to some degree the majority opinion in Fields. 180 Although I think the Fields' dissent is probably the better view, it also becomes unnecessary if Town of Greece's nondiscrimination proviso is taken seriously. For that reason, if I were the one writing the opinion on this issue, I would likely not reach the historical tradition question and turn instead directly to applying Justice Kennedy's nondiscrimination mandate.

Doing that, and moving on to the fourth inquiry of my restatement of Marsh and Town of Greece, the question becomes whether excluding atheists and other secularists from giving invocations counts as "discrimination." Discrimination, of course, can mean many things, but given the seemingly constitutional source of the nondiscrimination requirement and the specific setting posed by issues of legislative prayer, two dimensions of the Court's nondiscrimination jurisprudence seem most relevant: the requirement that the government treat all religions equally and the requirement that the government not distinguish among speakers in a designated public forum based on their viewpoint. Both of these requirements point in the same direction-excluding secularist invocations is unconstitutional.

First, the proposition that the government may not favor one religion over another religion is about as fundamental as any principle can be under the Religion Clauses. As the Court famously put it in the 1982 case of Larson $v$. Valente, "[t]he clearest command of the Establishment Clause is that one religious denomination cannot be officially preferred over another."181 In the context of legislative invocations, this must mean that the government cannot favor those who believe in a god or many gods over those who sincerely believe that there is no god or higher power. Whatever one may think about whether atheism, or other comprehensive belief systems that reject the existence of a god, constitute "religions" outside of the constitutional context, it has to be the case that they are religions for purposes of the Establishment Clause. Otherwise, the government could promote the idea that there is no god as literal truth - a view that virtually nobody believes is correct. Even the majority opinion in Fields recognized that groups that

180. See Barker v. Conroy, 921 F.3d 1118, 1130 (D.C. Cir. 2019); Fields, 936 F.3d at 1149 .

181. Larson v. Valente, 456 U.S. 228, 244 (1982). 
deny the existence of god are properly understood as "religions," when it stated the following: "The nontheistic organizations that brought this challenge may be 'religions' for First Amendment purposes. Indeed, the Supreme Court has moved considerably beyond the wholly theistic interpretation of the term religion. Its understanding of religion now includes nontheistic and atheistic beliefs, as well as theistic ones."182 It may be the case that allowing someone to give a Christian prayer before a legislative session does not violate the Establishment Clause, but that most definitely does not mean that the legislature can allow someone to give a Christian invocation but refuse to allow someone who does not believe in god to give a similar invocation. The former proposition follows from Marsh and Town of Greece, but the latter does as well, through Town of Greece's common-sense, fundamental-principleincorporating, nondiscrimination requirement. 183

Second, the idea that under the First Amendment's Free Speech Clause the government may not discriminate against speakers on the basis of the viewpoint that they are espousing is only slightly less fundamental than the requirement of denominational neutrality under the Religion Clauses. As the Court wrote in the flag-burning case of Texas $v$. Johnson: "[i]f there is a bedrock principle underlying the First Amendment, it is that the government may not prohibit the expression of an idea simply because society finds the idea itself offensive or disagreeable."184 Nor does this principle change simply because the speech takes place on government property or within the context of a government institution. In those cases, the proper analysis looks to the so-called public-forum doctrine, which dictates that regardless of whether the speech is taking place in a traditional public forum, a designated public forum, or even a non-public forum, the government may still not discriminate against speech on the basis of viewpoint.185 Indeed, this is the principle under which the Supreme Court has held repeatedly that if a public school opens its

182. Fields, 936 F.3d at 153 (citations omitted).

183. See Town of Greece v. Galloway, 572 U.S. 565, 585-86 (2014).

184. Texas v. Johnson, 491 U.S. 397, 414 (1989).

185. See, e.g., Cornelius v. NAACP Legal Defense \& Educ. Fund, Inc., 473 U.S. 788, 806 (1985) ("[A]ccess to a nonpublic forum can be based on subject matter and speaker identity so long as the distinctions drawn are reasonable in light of the purpose served by the forum and are viewpoint neutral."). 
property for use by after-school clubs and the like, it cannot exclude religious groups from using that property on the same terms that nonreligious groups are allowed to use it.186 Although it is not entirely clear whether a legislative invocation program is best characterized as a designated public forum or a non-public forum (my own view is that it is best understood as a designated public forum because it is intentionally opened up for a good deal of speech), ultimately it does not matter since even in a non-public forum, the Court has held that regulations of speech in such a place must be both reasonable and viewpoint-neutral.187 By allowing religious people of all different sects and stripes to give invocations but excluding those who do not believe in any divine being from speaking, the various jurisdictions that have adopted secularist exclusion policies have clearly discriminated against secularists on the basis of their viewpoint. Finding this exclusion unconstitutional should therefore not be a particularly difficult task.

Although a straight-forward application of the relevant cases and constitutional principles should be sufficient to invalidate secularist exclusion policies, any judge or court who feels it either necessary or desirable to consider the pragmatic consequences of a decision one way or the other on the issue should find convincing practical reasons to find exclusion of secularists unconstitutional. These reasons are detailed above 188 and involve, first and foremost, the importance of religious pluralism in public life. From the perspective of religious pluralism, legislative prayer practices ought to strive to include speakers representing as many religious and nonreligious traditions as possible. This must include not only representatives of minority religious beliefs, but those of nonreligious belief systems as well. Allowing secularists and other nonbelievers to give occasional invocations before legislatures and town meetings will empower members of an otherwise marginalized group, send a symbolic message that everyone is an equal member of the community, and allow secularists to teach others what it means to be a nonbeliever, thus perhaps even leading to mutual understanding, respect, and social peace. And, as the dissent in Fields persuasively explained, nothing is lost by allowing

186. See, e.g., Lamb's Chapel v. Ctr. Moriches Union Free Sch. Dist., 508 U.S. 384 (1993).

187. See Barker v. Conroy, 921 F.3d 1118, 1129-30 (D.C. Cir. 2019).

188. See id. 
nonbelievers to give invocations; a secular invocation is just as capable of lending gravity to the meeting and performing the other functions of legislative prayer as religious invocations are.189

None of this is to say that legislatures and town boards are foreclosed from placing some guidelines on what kinds of invocations can be given. Obviously, nobody is entitled to give an invocation about topics that are completely unrelated to the legislative or governing process; there is no constitutional right to give a speech before a town meeting about one's favorite hockey team or broccoli preparation method. Fortunately, exclusion of such invocations would not be unconstitutional. For one thing, as those invocations are neither about religion nor inspired by religion in any way, excluding them would not violate the denominational neutrality principle of Larson $v$. Valente. Moreover, because the Court has held that the government can insist on subject matter distinctions (as opposed to viewpoint-based distinctions) in both limited public forums and nonpublic forums, it should be possible for legislatures and other governing bodies to craft, if they so choose, a rule limiting invocations to ruminations about how fundamental beliefs about the world relate to the governing process. Of course, there may be difficulties with such a rule at the margins, but that is hardly a reason not to adopt a rule in the first place. In order to ensure that the state does not discriminate on the basis of religious viewpoint, however, I would suggest something like the following standard: the government may not exclude from its invocation program any speaker who represents a belief system that, if it were taught by a public school as truth (or otherwise declared as truth by the government), it would violate the Establishment Clause's prohibition on advancement of religion. As noted above, since public schools clearly cannot teach atheism or nonbelief as truth, secularists must be included in the set of people who are allowed to give invocations. 190

One final point about the majority's decision in Fields is worth making. The majority in that case argued that requiring the inclusion of nonbelievers in invocation programs would lead to "voices on the fringe" demanding the right to speak, which would in

189. Fields v. Speaker of the Pa. H.R., 936 F.3d 142, 170 (2019) (Restrepo, J., dissenting).

190. See id. at 166 . 
turn cause governmental bodies to cancel their guest invocation practices altogether, a negative result. The court wrote:

Taken too far, a nondiscrimination rule in legislative prayer provides a heckler's veto to voices on the fringe. If, in the name of nondiscrimination, the House must abide prayers from nontheists, Satanists, and groups that deride religion, it will stop accepting guest chaplains altogether. This will result in less diversity of religious expression-a "particularly perverse result." ... In matters of promoting religious diversity, the perfect should not be the enemy of the good. 191

This observation suffers from several serious problems. For one thing, since Satanists are in fact religious, 192 Town of Greece already clearly prohibits the government from excluding them from invocation practices on the basis of their viewpoint, so inclusion of atheists in addition to Satanists seems unlikely to, by itself, have the feared effect. But, more importantly, the paragraph gets constitutional law exactly backward. The nondiscrimination mandates that flow from various constitutional provisions are designed to protect voices on the fringe. That is their purpose. Popular voices do not need constitutional protection because they will prevail in the democratic process. It is precisely the nontheists, Satanists, and other religious minorities that need and deserve the protection of the First Amendment. If it turns out that the state is so worried about letting unpopular minorities speak before government meetings that it changes its invocation policy to exclude guest speakers altogether, that is the state's prerogative, just as it was the prerogative of localities in the 1950s to close public swimming pools altogether rather than to allow African-Americans to swim alongside whites. The state's intolerance and prejudice toward minorities, in other words, cannot be used as an argument in favor of discrimination. The fact that the Third Circuit majority thought it was proper to rely on such an argument truly renders most of the rest of its analysis untrustworthy and unpersuasive.

191. Id. at 157 .

192. See, e.g., Satanic Temple v. City of Scottsdale, 423 F. Supp. 3d 766, 775-78 (2020). 


\section{CONCLUSION}

Over the course of the last few decades, the Supreme Court has largely reduced the Establishment Clause to an empty shell. As a result, religion now has greater access to public money, institutions, and property than perhaps ever before. All of the cases in which the Court has allowed such increased access have, of course, involved claims by Christians, and with the results consistently coming out in their favor, the Christian majority has jumped on them to infiltrate public life with Christian symbols, speeches, and messages. But the Supreme Court has also consistently held that the government may not discriminate on the basis of religion-as a result, religious minorities of all types, including atheists and other secularists, have also begun taking advantage of the Court's jurisprudence to participate in public life by putting up their own symbols and displays on public property, starting their own afterschool clubs on public school property, asking for government funding, and-as detailed in this Article-giving their own invocations before government bodies. 193 This increased religious pluralism in public life might, from the perspective of minorities, not be preferable to a secular public square in which the government supports no religion at all, but it is at least better than an entirely Christian public square. The move by several jurisdictions to exclude secular invocations runs directly counter to the Court's nondiscrimination, pro-pluralism approach to the Establishment Clause and should be rejected. The government should allow, or indeed even encourage, secularists to partake in invocation programs in order to promote religious pluralism in American public life. And, if the government insists on excluding secularists, then it will be up to the federal courts to hopefully reverse the current disturbing trend exemplified by the Third and D.C. Circuits and declare these secular exclusion policies unconstitutional under both the Religion Clauses and the First Amendment's Free Speech Clause.

193. See generally WEXLER, supra note 1. 